gramme come at a particularly crucial stage in the development of the United States project under the auspices of the Geological Survey. Recently an increasing amount of attention has been paid to the public policy, aspects of prediction with, at least in some people's opinion, a concomitant build up in the public expectation that scientists are going to be able to deliver the goods in the very near future. Yet many seismologists privately entertain serious doubts that the premonitory symptoms are anything like unambiguous enough to warrant going public for some years to come. Three weeks ago Dr V. E. McKelvey, Director of the Geological Survey, was saying at a conference on earthquake warning and response, "we are now entering an age when scientific instruments are detecting geophysical signals that can be interpreted to forecast earthquake occurrence'. Many would have preferred him to have put this age five or ten years in the future while some very difficult work is being done. Unfortunately, although the Chinese results are very exciting indeed, they may give the false impression that the United States is in for a similar pay off. This is rather unlikely. Foreshocks, the means by which the Chinese pinned down the time of the quake so accurately, are a relatively rare occurrence before major events, and other techniques used such as telluric currents, migration of seismicity and radon levels in ground water have yet to show their usefulness in the United States.

One thing is indisputable, however. The Chinese work will have acted as a shot in the arm to seismologists in all other countries engaged in prediction research. And by all accounts there is more excitement still to come.

\section{Messengers in minicells}

from $M . R$. Blundell

THE first experiments demonstrating the existence of messenger RNA in bacteria were published in 1961 . One of the criteria for identification of mRNA was its short lifetime, which permits a rapid halt in synthesis of a specific protein, but our knowledge of the processes responsible for inactivation and degradation of mRNA remains very incomplete fourteen years later.

We know that degradation proceeds from the $5^{\prime}$ to the $3^{\prime}$ end of mRNA (Morikawa and Imamoto, Nature, 223, 37 ; 1969) but it is clear that the $5^{\prime}$ exonuclease activity called ribonuclease $\mathrm{V}$ (Kuwano, et al., J. molec. Biol., 51, 75 ; 1970) cannot be responsible alone for mRNA degradation (Imamoto and Schlessinger, Molec, gen. Genet., 135, 29; 1974).
What was regarded as merely a scavenging process has taken on new significance with the discovery that individual messages in the same Escherichia coli cell can have different decay rates with half-lives ranging from $40 \mathrm{~s}$ upwards at $37^{\circ} \mathrm{C}$ (Marrs and Yanofsky, Nature new Biol., 234, 168; 1971; Blundell et al., Nature new Biol., 238, 46; 1972; Craig, et al., J. molec. Biol., 71, 701; 1972, and others). Even messages in the same polycistronic mRNA can have quite different decay rates.

Hirashima, Childs and Inouye ( $J$. molec. Biol., 79, 373; 1973) discovered a message with a particularly long functional half-life, $11.5 \mathrm{~min}$ at $37^{\circ} \mathrm{C}$, which codes for a low molecular weight lipoprotein of the outer membrane of E. coli. Both et al. (J. molec. Biol., 67, 199 ; 1972) presented measurements of the secretion of an extracellular protease by Bacillus amyloliquefaciens which could be interpreted in terms of a mRNA stable for up to $80 \mathrm{~min}$ at $30{ }^{\circ} \mathrm{C}$, but subsequently, they concluded (Glenn et al., J. molec. Biol., $73,221 ; 1973)$ that this message was not especially stable, but was instead made in very large quantities. In hybridisation experiments, however, Brown and Coleman (J. molec. Biol., 96, 345; 1975) could not find such quantities of mRNA, or any especially stable mRNA in cultures of $B$. amyloliquefaciens.

Now Levy (Proc. natn. Acad. Sci. U.S.A., 72, 2900; 1975) reports the presence of a small quantity of very long lived mRNA in $E$. coli minicells, structures about one tenth the size of whole cells which are made in abnormal cell divisions of an $E$. coli mutant and lack the $E$. coli chromosome. Plasmid DNA that segregates into minicells is transcribed and translated, but plasmid-less minicells do not make DNA or RNA. Levy observes, however, that ${ }^{35} \mathrm{~S}$-methionine is incorporated by freshly isolated minicells into hot trichloroacetic acid precipitable material at 0.2 to $0.5 \%$ of the rate in whole cells. The incorporation is sensitive to chloramphenicol, so it is presumably ribosomal polypeptide synthesis. Protein synthesis decays during incubation at $37^{\circ} \mathrm{C}$ with a half-life of about $80 \mathrm{~min}$, and is unaffected by rifamycin. The major products of protein synthesis in plasmid-free minicells are four polypeptides of the outer cell membrane, one of these being the lipoprotein coded by the long lived mRNA studied by Hirashima et al.

We can, therefore ask, as does Levy, why the messages for membrane proteins should be so stable in minicells. Minicells containing an $\mathbf{R}$ factor continue to make short lived mRNA which codes for other proteins, so mRNA can be degraded in minicells, but no comparison of the decay rates of $\mathrm{R}$ factor messages in whole cells and minicells is presented. One possibility, since minicells form from the poles of cells, is that the cell extremities, and therefore minicells, are relatively deficient in specific nuclease(s).

We may also ask why membrane proteins should have abnormally stable message. To investigate this question Hirashima, Wang and Inouye are now developing a cell-free translation system which synthesises the lipoprotein when purified mRNA is added.

\section{Unexpected pro- viruses in chronic infection}

\section{from Robin Weiss}

RECENT reports by Zhdanov (Nature, 256, 471; 1975) and by Simpson and Iinuma (Proc. natn. Acad. Sci. U.S.A., $72,3230 ; 1975)$ promise to open up a new area of genetic exchange between RNA viruses and their hosts. These authors claim that some animal RNA viruses that conventionally replicate by means of RNA intermediates can under conditions of chronic infection form DNA "proviruses".

Simpson and Iinuma have studied a temperature sensitive mutant of respiratory syncytial (RS) virus in bovine embryo kidney (BEK) cells infected and maintained at the nonpermissive temperature of $39^{\circ} \mathrm{C}$. These $\mathrm{BEK} / \mathrm{RS}$ cells did not release RS virus or synthesise RS viral antigens detectable by immunofluorescence. However, even late passage cultures yielded infectious virus when co-cultivated with uninfected cells or when treated with agents such as halogenated pyrimidines. These findings led the authors to look for DNA proviruses of RS virus using transfection techniques as described by Hill and Hillova (Nature new Biol., 231, 261; 1971) for the provirus of Rous sarcoma virus. When HEp-2 cells were treated with DNA extracted from the $\mathrm{BEK} / \mathrm{RS}$ cell line infectious RS virus was recovered. A clonal analysis of the progeny $\mathrm{RS}$ virus indicated that some clones retained the special properties of the virus that initiated the chronic infectiontemperature-sensitive replication and heat-resistant virions-whereas other clones had lost one or both of these properties and more closely resembled wild-type RS virus. Simpson and Iinuma further showed that a chronically-infected cell line of HEp-2 cells, survivors of an infection with wild-type RS virus, similarly contained infectious DNA for RS virus.

Zhdanov's analysis is less detailed but wider ranging, and illustrates the same phenomenon of DNA provirus formation in cultures chronically in- 